\title{
Trade, skill-biased technical change and wages in Mexican manufacturing*
}

\author{
Mauro Caselli \\ School of Economics, University of New South Wales \\ Australian School of Business, Kensington, NSW 2033, Australia \\ Email:m.caselli@unsw.edu.au
}

This paper looks at the relative importance of competing stories, particularly trade liberalization and skill-biased technical change, to explain changes in the skill premium and the real wages of unskilled and skilled workers in Mexican manufacturing using plant-level data. The channel through which technical change is observed is changes in the domestic price of machinery and equipment due to the availability of new and cheaper machines. The analysis also looks at trade-induced skill-biased technical change by taking into account changes in the price of machinery and equipment caused by changes in the tariff rate specific to machinery and equipment. Instrumental variables, including the price of machinery and equipment in the US, are used to determine causality between the above effects and wages. Thus, the paper provides evidence for some recent findings in the literature that link trade liberalization, skill-biased technical change occurring through technology embodied in machines and increases in the skill premium.

Keywords: trade liberalization, skill-biased technical change, skill premium, real wages, Mexico, manufacturing.

JEL Classification: F14, J30, L60, O30.

*I thank Adrian Wood for many helpful comments and discussions. I am also grateful to Francis Teal, Beata Javorcik, Tony Venables, Alasdair Smith, Alan Woodland, seminar participants at the Asia-Pacific Trade Seminar, ETSG conference, EALE conference, University of Melbourne and Australian National University, and three anonymous referees. Special thanks go to Abigail Durán and Gerardo Leyva for granting me access to INEGI data at the offices of INEGI in Aguascalientes and to all INEGI employees who provided assistance and answered my questions, in particular to Gabriel Romero, Otoniel Soto and Armando Arallanes. I gratefully acknowledge that part of this research was financially supported by an Australian Research Council grant to Professor Alan Woodland. All errors are mine. 


\section{Introduction}

The last 30 years have witnessed an increase in wage inequality not only in developed countries (Katz and Murphy, 1992; Machin and Van Reenen, 1998), but also in some lowincome and many middle-income developing countries (Anderson, 2005; Goldberg and Pavcnik, 2007). This increase in wage inequality reflects both an increase in the relative wages of skilled to unskilled workers, due mainly to rising real wages of skilled workers and stagnant real wages of unskilled workers, and a rise in within-group inequality.

Given the potential economic consequences of this increase in inequality, much attention has fallen on the reasons behind such increase. Several competing theories have been put forward, mainly based on the observation of two recent phenomena. First, developing countries have become more integrated with the rest of the world, particularly through reductions in tariff rates, quotas and other non-tariff barriers. Traditional trade theory, in particular the Stolper-Samuelson theorem, predicts that the relative wages of skilled workers should decrease in developing countries, assuming that they are abundant in unskilled labour (Wood, 1994). While the widespread rise in the skill premium seems at odds with this traditional trade theory, Wood (1997) points out that Latin American countries, in many of which the rise in the skill premium was marked, were relatively skill abundant when they opened to trade in the 1980s.

Following the seminal paper by Melitz (2003), much of the trade literature has since moved on to consider the implications of firm heterogeneity for the effects of trade on wages. A general framework that allows for both classic (Heckscher-Ohlin-Vanek or Ricardo-Viner) and Melitz explanations is that developed in Bernard et al. (2009). This model, however, assumes that wages only vary across groups, as defined by skilled and unskilled workers, and sectors while they remain equal across firms within the same sector. Similarly, Vannoorenberghe (2011) and Harrigan and Reshef (2011) build models in which trade liberalization increases the skill premium equally across all firms as more productive and skill-intensive firms expand to serve the export market at the expense of less productive and less skill-intensive firms.

Firm-level wage premia can instead be found in several models embedding efficiency wages (Davis and Harrigan, 2011), fair wages (Egger and Kreickemeier, 2009; Amiti and Davis, 2012), or bargaining under search frictions (Helpman and Itskhoki, 2010; Felbermayr et al., 2011) into the Melitz (2003) model of trade with heterogeneous firms. While these papers look at how within-group or residual inequality between ex-ante identical workers is affected by trade liberalization, this paper will focus on differences in wages across skill groups and plants.

Second, since most of the world's technical progress originates in a few rich countries (Schmidt, 2010), which are relatively skill abundant, machinery and equipment, hereafter $\mathrm{M} \& \mathrm{E}$, tends to be complementary with skills (Krusell et al., 2000). When new technologies, such as personal computers, are adopted by firms in developing countries, they are thus likely to increase the relative demand for skilled workers, a process that has been referred to in the literature as exogenous skill-biased technical change, hereafter SBTC (see Acemoglu, 2002a;b). ${ }^{1}$

\footnotetext{
${ }^{1} \mathrm{~A}$ more nuanced version of the SBTC hypothesis is the task-based approach, as proposed by Autor et al. (2006) and Goos et al. (2009). This approach suggests that technological progress is complementary with abstract cognitive tasks, a substitute for routine tasks, and has little direct impact on manual
} 
As the debate continues regarding the relative importance of trade liberalization and SBTC as causes of the rise in the skill premium, a combined hypothesis has been suggested separately by Robbins (2003) and Acemoglu (2002a; 2003) and analysed further in several recent papers (Burstein and Vogel, 2009; Bustos, 2011; Riaño, 2009; Schmidt, 2010; Gallego, 2010; Csillag and Koren, 2011). These authors have put forward different models in which, as a country reduces its barriers to trade, firms find it more profitable to adopt new skill-biased technologies because either these technologies have become cheaper or their adoption is required for exporting. Through this channel, trade liberalization can raise the skill premium even in skill-scarce developing countries, a process which can be referred to as trade-induced SBTC.

While consensus is building up on the role played by trade-induced SBTC in the increase in the skill premium (Van Reenen, 2011), the literature is still designing effective strategies to identify the separate effects of SBTC and trade liberalization on the skill premium and real wages of unskilled and skilled workers within the same analysis, especially in the context of developing countries.

The purpose of this paper is, therefore, to conduct an econometric analysis of wages at the plant level in the Mexican manufacturing sector for the period 1984-1990 in a way that allows the influence of SBTC, measured by changes in the price of M\&E relative to the wholesale price index, and trade liberalization in both inputs and output goods to be isolated and quantified. The use of plant-level data makes possible to analyse the heterogeneous effects of cheaper M\&E and lower tariffs on wages depending on plants' propensity to invest in $\mathrm{M} \& \mathrm{E}$, export and import.

To isolate the effects of SBTC coming through cheaper M\&E and trade liberalization on wages, the paper needs to simultaneously rule out alternative explanations. Thus, the econometric analysis will control for the plant's export status (Verhoogen, 2008), foreign ownership (Feenstra and Hanson, 1997), offshoring of production stages from the US (Feenstra and Hanson, 1996), and the use of imported intermediate inputs (Goldberg et al., 2010; Kugler and Verhoogen, 2012). Robustness checks will also include combined regional, sectoral and year fixed effects to control for supply effects and more standard plant-level measures of SBTC, i.e., royalties paid on new technologies and M\&E imports (see the literature review by Chennells and Van Reenen, 1999).

With regards to trade-induced SBTC, the paper focuses on a specific channel coming through changes in the price of $\mathrm{M} \& \mathrm{E}$ in Mexico due to changes in the tariff rate on $\mathrm{M} \& \mathrm{E}$. However, trade-induced technical change could also happen through other channels, in particular output tariff changes. Gorodnichenko et al. (2010) and Bloom et al. (2011) suggest that the innovation strategy of firms depends on the level of competition in the goods markets, which, in turn, is affected by the level of output tariffs. This alternative mechanism will also be controlled for in the econometric analysis.

In order to identify causal relationships, the strategy adopted uses an instrumental variable (IV) approach implemented in the system GMM estimator and based on both "internal" instruments - i.e., lags of the endogenous variables - and an "external" instrument - i.e., the price of M\&E relative to the wholesale price index in the US.

tasks. This pattern of complementarity and substitutability, in turn, is the reason for the current job polarization in the United States (US) and Europe. The SBTC and job polarization hypotheses can be partly reconciled by assuming that skilled workers perform abstract tasks while unskilled workers perform routine and manual tasks. 
The paper shows that, after controlling for both plant- and industry-level variables, lower prices of M\&E lead to an increase in the skill premium and real skilled wages, but only in large plants and in those that invest more in M\&E. Also, changes in the price of $\mathrm{M} \& \mathrm{E}$ are affected by changes in the price of M\&E in the US and lower tariffs on M\&E. The results also reveal that trade liberalization in intermediate inputs has a negative and robust effect on the skill premium in plants that import a larger share of their intermediate inputs, which is in line with recent findings by Amiti and Cameron (2011), while trade liberalization in final goods has a non-robust positive effect on the skill premium and the real skilled wages in plants that export a larger share of their sales.

In terms of the magnitude of the estimated effects, changes in the price of M\&E can explain one tenth of the increase in the skill premium during the period 1984-1990. This is to be considered a lower-bound estimate since this methodology cannot capture the effects of SBTC and trade liberalization that are homogeneous across sectors over time.

The results presented give rise to the following interpretation. Decreases in the price of $\mathrm{M} \& \mathrm{E}$ increase the demand for $\mathrm{M} \& \mathrm{E}$, especially in larger plants that invest more in $\mathrm{M} \& \mathrm{E}$, and lead to technical change due to new technology embodied in cheaper machines and favoured by lower tariffs on M\&E. In turn, in an economy with equipment-skill complementarity, investment in $\mathrm{M} \& \mathrm{E}$ tends to favour skilled workers, at least in those large plants that invest more in $\mathrm{M} \& \mathrm{E}$, by pushing up the relative demand for skills.

These results are also consistent with an interpretation based on capital deepening through investment in M\&E. However, assuming that such investments make available new and better machines that lead to a shift in the production function, the former interpretation is more relevant and it is the preferred one in the rest of the paper.

Mexico has been frequently chosen as a country in which to study the effects of trade liberalization on wages. Not only did the country go through a substantial trade liberalization process in the 1980s, with production-weighted average tariffs declining from 28.5 percent in 1985 to 12.5 percent in 1990 (Ten Kate, 1989; 1992) and trade as a fraction of GDP rising from 25 percent to 39 percent during the same period, but also the skill premium increased by almost 30 percent between 1985 and $1994 .^{2}$

The popularity of the topic, however, does not imply that the literature has been able to address all the issues. A limitation of most previous work on the liberalization process in Mexico is its focus only on wage inequality, neglecting real wages. Another limitation is the literature's reliance on the Stolper-Samuelson theorem (Hanson and Harrison, 1999; Feliciano, 2001; Esquivel and Rodríguez-López, 2003). None of the studies based on the 'mandated wage' approach finds strong evidence for the channel through which the Stolper-Samuelson theorem works in theory, since the correlation between changes in output prices and relative wages at the industry level is extremely low (Riaño, 2009).

Other studies have investigated alternative possible causal connections between greater openness and the increase in wage inequality. Among them, Feenstra and Hanson (1997) argue that FDI towards maquiladoras, assembly plants for re-exports, has been the cause of the increase in relative skilled wages after the trade liberalization of 1985-1987 and Verhoogen (2008) shows that new export opportunities following the 1994 Mexican peso devaluation led to an increase in within-industry wage inequality due to quality upgrading

\footnotetext{
${ }^{2}$ The skill premium remained stable in subsequent years (Riaño, 2009), which makes it difficult to identify the effects of reductions in tariffs, due to the introduction of the North American Free Trade Agreement in 1994, on wages.
} 
by the most efficient plants.

The remainder of the paper is organized as follows. Section II describe the data used and some descriptive statistics. Section III outlines the identification strategy and the econometric specification. Section IV presents the results of the regression analysis and Section V concludes.

\section{Data}

The data used in this paper come mainly from the Encuesta Industrial Anual (Annual Industrial Survey, EIA), provided by the Instituto Nacional de Estadistíca y Geografía, INEGI, the national statistics institute of Mexico. The unit of observation in the dataset is a plant rather than a firm, which may pose problems of identification because firms may re-organize production among the plants they own. ${ }^{3}$ The database contains information on 3218 manufacturing plants for the period 1984-1990 (for a total of 22526 plant-year observations) and it is by design a balanced panel that covers 85 percent of all manufacturing output value. The data distinguish 129 six-digit industries, classified according to the CMAE75 (Clasificación Mexicana de Actividades Económicas, 1975). The final sample, after cleaning, contains 12761 observations, that is, 1823 per year. ${ }^{4}$

The database provides a wide array of information on each individual plant, including information on the total number of blue-collar workers, whose main activities include machine operation, production supervision, repair, maintenance and cleaning, and whitecollar workers, such as managers, administrators, professionals and salesmen, total number of hours worked for each type of worker, total remuneration, production, input use, stock of and investment in different capital goods, expenditures on royalties for the use of new technologies, imports of M\&E and materials, value of exports and the state (region) where the plant is located. Variables related to imports and exports are only available from 1986 onwards, therefore most of the analysis focuses on the period 1986-1990.

While the EIA includes information on the percentage of firms' social capital held by foreigners, this variable does not change over time for any of the plants included in the sample. Thus, the direct effects of FDI on wages are identified only through variations across plants. The survey does not include maquiladora plants, which excludes the possibility of a Feenstra and Hanson (1996) type mechanism. During this period, the Mexican economy also went through a process of privatization, but the EIA does not include any information on public ownership of the plants surveyed (see La Porta and López-De-Silanes, 1999 for the effects of privatization on productivity in Mexico).

Throughout the paper, skilled wages are measured as the average daily wages for white-collar workers, unskilled wages as the average daily wages for blue-collar workers and the skill premium, the measure of wage inequality, as the ratio of skilled to unskilled wages. Therefore, the paper distinguishes between skilled and unskilled workers on the basis of occupation rather than education, which is not available in the EIA. The classification of workers into blue- and white-collar groups in order to approximate skilled and unskilled labour respectively is not ideal because skills are better described by classifications based on educational characteristics (Gonzaga et al., 2006; Bustos, 2007), and

\footnotetext{
${ }^{3}$ A quarter of the plants surveyed in the EIA are part of multi-plant firms (Iacovone, 2008).

${ }^{4}$ For more information on the EIA and the cleaning procedure see Iacovone, 2008, and Riaño, 2009.
} 
Table 1: Descriptive statistics

\begin{tabular}{lrrrr}
\hline \hline & 1986 & & 1990 \\
& Mean & S.D. & Mean & S.D. \\
\hline Skill premium & 2.06 & 0.78 & 2.72 & 1.55 \\
Real skilled wages (1994 pesos per day) & 120.91 & 53.94 & 146.43 & 76.94 \\
Real unskilled wages (1994 pesos per day) & 60.84 & 23.89 & 58.41 & 27.98 \\
Price of M\&E (Mexico) & 1.49 & 0.17 & 1.21 & 0.11 \\
Price of M\&E (US) & 0.17 & 0.01 & 0.16 & 0.01 \\
Tariff rate on final goods & 0.41 & 0.25 & 0.15 & 0.04 \\
Tariff rate on inputs & 0.23 & 0.08 & 0.11 & 0.02 \\
Tariff rate on M\&E & 0.10 & - & 0.10 & - \\
\hline \hline
\end{tabular}

because changes in the skill premium based on occupation may be driven by compositional shifts in the education of workers within the occupation categories. However, this categorization is very common in the literature because it is often the only one available in firm-level data (Berman et al., 1994; Feenstra and Hanson, 1996; Leamer, 1998; Meschi et al., 2009). Berman et al. (1994) also argue that it yields results similar to those obtained using education categories.

The price of M\&E in Mexico, alongside the prices of other types of capital, is provided by the INEGI. The following analysis uses the price of M\&E relative to the wholesale price index. The price of M\&E in the US, which is also divided by the wholesale price index, is taken directly from the Bureau of Economic Analysis (BEA). While the price of M\&E in Mexico is available for 46 four-digit industries according to the CMAE75, the price of M\&E in the US is available for 19 industries according to the Standard Industrial Classification. A table of correspondence provided by INEGI is therefore used to match the two industry classifications.

Tariff rates are taken from Ten Kate $(1989 ; 1992)$. The data available include the tariff rate on $\mathrm{M} \& \mathrm{E}$, which only varies over time, production-weighted average tariff rates on final goods and tariff rates on inputs, calculated by combining output tariff rates, excluding tariffs on M\&E, with the input-output tables provided by the INEGI.

The Herfindahl-Hirschman Index, a measure of concentration at the industry level, is calculated using output value data from the EIA. ${ }^{5}$ The degree of unionization in an industry is calculated as the percentage of workers that belong to a recognized trade union, taken from the National Survey on Household Income and Spending (ENIGH) provided by the INEGI.

Table 1 shows the descriptive statistics of some of the variables described above for 1986 and 1990. The skill premium increased substantially, from 2.06 in 1986 to 2.72 in 1990, mainly due to a large increase in the wages of white-collar workers, while the wages of blue-collar workers only decreased slightly. During this same period, there was a significant decline in the price of M\&E, both in Mexico and in the US, as well as in tariff rates on both final goods and inputs. It should be noted that while tariffs decreased on average throughout this period, they increased slightly after 1989. This is particularly evident for the tariff rate on M\&E that decreased down to $3 \%$ in 1989, but then increased back to $10 \%$ in 1990, the same level as in 1986.

\footnotetext{
${ }^{5}$ The following formula is used to calculated the Herfindahl-Hirschman Index: $h h i_{i}=\sum_{k}^{n} s_{k, i}^{2}$, where $s_{k, i}$ is the share of plant $k$ in industry $i$ and $n$ is the number of plants in industry $i$.
} 


\section{Identification strategy and econometric specification}

In order to study the effect of trade liberalization and SBTC on the skill premium, this paper adopts the reduced-form model for wages, suggested by Doms et al. (1997),

$$
w=w(c, o, v)
$$

where $w$ can be the relative wage of white- to blue-collar workers as well as their real wages, $c$ is the proxy for SBTC, $o$ represents different measures of trade liberalization and $v$ stands for other regressors to be included in the regression analysis, including the lagged dependent variable.

In the main specification, SBTC is proxied by the industry-level price of M\&E. The intuition is that technological improvements may come in the form of a decrease in the domestic price of equipment capital (Krusell et al., 2000). Provided that there is complementarity between $\mathrm{M} \& \mathrm{E}$ and white-collar workers, or at least lower substitutability between these two factors of production compared to that between M\&E and blue-collar workers, cheaper M\&E may then favour white-collar workers. Moreover, the analysis will look at the heterogeneous effects of M\&E by focusing on larger plants - since these use $\mathrm{M} \& \mathrm{E}$ more intensively and invest more in $\mathrm{M} \& \mathrm{E}$ - and on plants with investment in $\mathrm{M} \& \mathrm{E}$ throughout the period above the median level.

The price of M\&E is potentially endogenous since factor prices are determined contemporaneously. Therefore, an IV approach is implemented by including both internal instruments, i.e., lagged values of dependent variables, and an external instrument, the price of M\&E in the US. The intuition is that when the price of M\&E decreases in the US exogenously, due for example to the information technology 'revolution', the same is likely to happen to the price of M\&E in Mexico since imports of M\&E from the US make up at least two thirds of total M\&E imports in Mexico according to UN COMTRADE data. In turn, the decrease in the price of M\&E increases the demand for it and, assuming that M\&E is more complementary with white- than blue-collar workers, leads to SBTC, not only in the US but in Mexico too. Moreover, this paper takes into account trade-induced SBTC by showing in a separate regression that the price of M\&E in Mexico is also affected by trade policy via the tariff rate on M\&E.

The requirement for any IV approach is that the instrument is both informative and valid. Regarding the informativeness of the instrument, industry-level regressions will show that there is a significant positive relationship between the price of M\&E in the US and the price of M\&E in Mexico controlling for other regressors, including the tariff rate on M\&E. Moreover, the internal instruments help in addressing any concerns of weak instrumentation. For the instrument to be valid, it must be uncorrelated with the residual in the main equation determining wages. This is the case if the price of $\mathrm{M} \& \mathrm{E}$ in the US is unaffected by the demand for M\&E in Mexican manufacturing, which seems a plausible assumption given that exports of M\&E to Mexico make up only six percent of total M\&E exports from the US according to UN COMTRADE data.

To measure trade liberalization, the analysis includes both input and output tariff rates at the industry level and their interaction, respectively, with the share of exports in total sales and the share of imported raw materials in total material costs at the plant level. Following the approach by Amiti and Davis (2012) and Amiti and Cameron (2011), 
the interaction terms are added to analyse whether the effects of trade liberalization are industry-wide or heterogeneous and affect more plants that import and export.

Even though the 1985-1987 liberalization process in Mexico was imposed by the external circumstances arising with the debt crisis and its main emphasis was on reducing average tariff rates as well as the dispersion in tariff rates, tariff rates may still be endogenous. In particular, future tariff rates may be correlated with current productivity (Topalova, 2004) or with industries' skill intensity (Revenga, 1997; Feliciano, 2001).

The data show that tariff rates are indeed correlated with past values of productivity - measured using the Levinsohn and Petrin (2003) approach - and the share of whitecollar workers at the industry level. However, the degree of tariff reduction does not depend on any industry characteristic, but depends only on the initial tariff level (results are available upon request). Thus, extending the approach in Goldberg and Pavcnik (2005), the paper addresses the endogeneity of tariffs by using the lagged levels of tariffs as instruments for tariffs in differences.

To isolate the effects of SBTC coming through cheaper M\&E and trade liberalization on wages, the reduced form model also includes other controls to proxy for alternative explanations for the changes in wages. Thus, the econometric analysis controls for the plant's export status, foreign ownership and the use of imported intermediate inputs. A measure of industry concentration, the Herfindahl-Hirschman Index, is included to account for a potential alternative mechanism through which trade-induced technical change could happen. The inclusion of state-year, sector-year (not shown in the tables) and state-sector-year fixed effects in the robustness checks makes possible to control for offshoring of production stages from the US, even though information on the output value of maquiladoras is missing, and for differential changes in labour supply across industries, Mexican states and industries within states.

Based on the identification strategy just described, the following equation is to be estimated for relative wages:

$$
\begin{aligned}
\ln (w s / w u)_{k i t}= & \alpha_{0}+\beta_{1} \ln (w s / w u)_{k i t-1}+\beta_{2} \ln p_{i t}+\beta_{3} \ln \text { taro }_{i t}+ \\
& \beta_{4} \ln \text { taro }_{i t} * \ln \text { expsh }_{k i t}+\beta_{5} \ln \text { tari }_{i t}+\beta_{6} \ln \text { tari }_{i t} * \ln \text { impsh }_{k i t}+ \\
& \beta_{7} \ln \text { tarme }_{t} * \ln \text { impmesh }_{k i t}+\beta_{8} X_{k i t}+\beta_{9} W_{i t}+\alpha_{t}+\alpha_{k}+\epsilon_{k i t}
\end{aligned}
$$

where $w s / w u$ is the skill premium measured by the relative wage of white- to blue-collar workers, $p$ is the price of M\&E in Mexico, taro is the tariff rate on final goods, expsh is the share of exports in total sales, tari is the tariff rate on intermediate inputs, impsh is the share of imported materials in total material costs, tarme is the tariff rate on M\&E, impmesh is the share of M\&E imported, $X$ is a vector of plant-level controls, including the alternative plant-level proxies for SBTC, $W$ is a vector of industry-level controls, $\alpha_{t}$ represents year fixed effects, $\alpha_{k}$ represents plant fixed effects, $\epsilon$ is the error term, subscript $k$ indexes plants, $i$ industries and $t$ years.

The plant-level variables, $X$, will include the ratio of total capital to valued added, the share of exports in total sales, the share of materials imported, the share of M\&E imported and the share of firms' social capital owned by foreigners, a measure of FDI.

Including the lagged dependent variable means that traditional panel data estimators are subject to dynamic panel bias (Roodman, 2009). Given the large number of observations, difference and system GMM are consistent estimators and both allow for the 
inclusion of internal and external instruments. However, due to the highly persistent nature of wages, for example because of long-term contracts or "sticky" wages, it is possible to gain precision by exploiting additional moment restrictions, as done by the system GMM estimator (Bobba and Coviello, 2007; Roodman, 2009). ${ }^{6}$ This estimator uses not only lagged levels as instruments in the equation in differences, as done by the difference GMM estimator, but also lagged differences as instruments in the equation in levels and it is therefore the preferred estimator for this analysis.

The additional industry-level variables, $W$, included in this model are the HerfindahlHirschman Index and the degree of unionization, a proxy for labour market conditions and the possible difficulties in hiring and firing workers, both of which can have a direct effect on wages (Fairris and Levine, 2004). Through the time dummies, the analysis accounts for economy-wide changes, which include not only exchange rate movements and minimum wage legislation, but also additional effects of trade liberalization and SBTC that cannot be identified using the present strategy, for example if there is a high degree of labour mobility. Therefore, the effects of trade liberalization and SBTC occurring through the $\mathrm{M} \& \mathrm{E}$ price channel are likely to be lower bound estimates.

An additional reduced-form equation is estimated to check the informativeness of the price of M\&E in the US as an instrument and to determine how the price of M\&E in Mexico changes due to exogenous SBTC, measured by the price of M\&E in the US, and trade-induced SBTC, measured by the tariff rate specific to M\&E. This is necessary because system GMM does not report the results of this type of regression, which is equivalent to the first-stage regression in a simpler two-stage least squares estimation. The equation to be estimated is as follows:

$$
\ln p_{i t}=\gamma_{0}+\gamma_{1} \ln \text { pus }_{i t}+\gamma_{2} \ln \left(\text { tarme }_{t}+1\right)+\gamma_{3} W_{i t}+\eta_{i}+\nu_{i t}
$$

where pus is the price of M\&E in the US, $W$ represents additional industry-level regressors also included in equation (2), $\eta_{i}$ are industry fixed effects and $\nu$ is the error term. Year fixed effects are not included because they would not make it possible to identify the coefficient on the tariff rate specific to $\mathrm{M} \& \mathrm{E}$. However, an alternative specification that only includes the price of M\&E in the US and year fixed effects is also estimated.

A simple variation of equation (2) can be estimated to look at real white- and bluecollar workers' wages. This yields

$$
\begin{aligned}
\ln w s_{k i t}= & \alpha_{0}+\beta_{1} \ln w s_{k i t-1}+\beta_{2} \ln p_{i t}+\beta_{3} \ln \text { taro }_{i t}+ \\
& \beta_{4} \ln \text { taro }_{i t} * \ln \text { expsh }_{k i t}+\beta_{5} \ln \text { tari }_{i t}+\beta_{6} \ln \text { tari }_{i t} * \ln \text { impsh }_{k i t}+ \\
& \beta_{7} \ln \text { tarme }_{t} * \ln \text { impmesh }_{k i t}+\beta_{8} X_{k i t}+\beta_{9} W_{i t}+\alpha_{t}+\alpha_{k}+\epsilon_{k i t} \\
\ln w u_{k i t}= & \alpha_{0}+\beta_{1} \ln w u_{k i t-1}+\beta_{2} \ln p_{i t}+\beta_{3} \ln \text { taro }_{i t}+ \\
& \beta_{4} \ln \text { taro }_{i t} * \ln \text { expsh }_{k i t}+\beta_{5} \ln \text { tari }_{i t}+\beta_{6} \ln \text { tari }_{i t} * \ln \text { impsh }_{k i t}+ \\
& \beta_{7} \ln \text { tarme }_{t} * \ln \text { impmesh }_{k i t}+\beta_{8} X_{k i t}+\beta_{9} W_{i t}+\alpha_{t}+\alpha_{k}+\epsilon_{k i t}
\end{aligned}
$$

where $w s$ stands for real white-collar workers' wages and $w u$ for real blue-collar workers' wages.

\footnotetext{
${ }^{6}$ Estimation of univariate $\mathrm{AR}(1)$ processes gives estimates of the autoregressive coefficients for the relative wage of white- to blue-collar workers and their real wages that are at least 0.8 , thus all very persistent (see Bobba and Coviello, 2007, and Blundell and Bond, 1998).
} 


\section{Econometric analysis}

\section{Results for the skill premium}

Table 2 presents the baseline results for the skill premium based on the estimation of equation (2) via system GMM. The Wald tests show that all regressions are significant as a whole, while the $\operatorname{AR}(1)$ and $\operatorname{AR}(2)$, the Arellano-Bond tests for serial correlation of the residuals, detect only first-order serial correlation and reject the hypothesis of higher-order serial correlation. Therefore, the system GMM estimator can use the second and higher-order lags of the dependent variable as instruments, but only one lag of the endogenous variables is used in all the following regressions to avoid problems of too many instruments (Roodman, 2009). While the Hansen test of overidentifying restrictions does not reject the null hypothesis of exogeneity of instruments in all the specifications, the Sargan test of overidentifying restrictions fails. Moreover, the difference-in-Hansen test does not reject the exogeneity of the price of M\&E in the US as an instrument by itself. These tests, which are not reported, should not be relied upon too faithfully because the Hansen-type tests are weakened by many instruments and the Sargan test is prone to weakness (Roodman, 2009) and it tends to become more significant as the number of observations grows large (Meschi et al., 2009).

Moving on to the different specifications reported, column (1) includes only the lagged dependent variable, the $\log$ of the price of $M \& E$ and year fixed effects for all available observations. The coefficient on the lagged values of relative wages is always positive and significant and with a coefficient less than one. The coefficient on the log of the price of $\mathrm{M} \& \mathrm{E}$ in Mexico is negative and only just significant at the $10 \%$ level.

The specification in column (2) includes the same explanatory variables, but the sample consists only of larger plants, here defined as those having more than 100 employees following the EIA sample stratification. This specification tests whether the effects of SBTC coming through changes in the price of M\&E are heterogeneous and accrue only to larger plants. The coefficient on the price of $\mathrm{M} \& \mathrm{E}$ is negative, of larger magnitude and significant at the $5 \%$ level. Decreases in the price of M\&E lead to increases in relative wages, but only in larger plants.

Regarding the magnitude of the coefficients related to the price of M\&E, a $10 \%$ decrease leads to an increase in the relative wage of white- to blue-collar workers by approximately 0.05 points in larger plants. Thus, variation in the price of M\&E can account for one tenth of the increase in relative wages during the 1986-1990 period. The magnitude of the effect is similar in the following specifications.

Column (3) drops the price of M\&E and adds the trade-related variables. The only variable that has a robust effect on relative wages is the interaction between input tariff rates and the share of imported intermediate inputs. The positive coefficient suggests that input tariff liberalization has a negative effect on the relative wage of white- to blue-collar workers in plants that import larger shares of intermediate inputs. This agrees with the results in Amiti and Cameron (2011) for Indonesia and can be explained by reinterpreting the Stolper-Samuelson theorem at the plant level and assuming that intermediate inputs are more skill intensive than final goods.

The price of $M \& E$ and all trade-related variables are added in the same specification in column (4) alongside with additional plant- and industry-level controls. In particular, the log of FDI, defined as the share of firms' social capital held by foreigners, is included 
Table 2: The effects of trade and SBTC on the skill premium

\begin{tabular}{|c|c|c|c|c|c|}
\hline \multicolumn{6}{|l|}{$\overline{\text { Dep. var.: Skill premium }}$} \\
\hline & $(1)$ & $(2)$ & $(3)$ & $(4)$ & $(5)$ \\
\hline & All & Plants w/ & Trade & Additional & $>$ median \\
\hline & plants & $>100$ empl. & variables & controls & M\&E inv. \\
\hline \multirow[t]{2}{*}{ Skill premium (-1) } & 0.66 & 0.69 & 0.69 & 0.69 & 0.57 \\
\hline & $(0.06)^{\star \star \star}$ & $(0.08)^{\star \star \star}$ & $(0.08)^{\star \star \star}$ & $(0.08)^{\star \star \star}$ & $(0.04)^{\star \star \star}$ \\
\hline \multirow[t]{2}{*}{ Log M\&E price } & -0.32 & -0.56 & & -0.52 & -0.55 \\
\hline & $(0.17)^{\star}$ & $(0.23)^{\star \star}$ & & $(0.23)^{\star \star}$ & $(0.25)^{\star \star}$ \\
\hline \multirow[t]{2}{*}{ Log input tariffs } & & & -0.06 & -0.03 & -0.01 \\
\hline & & & $(0.06)$ & $(0.06)$ & $(0.06)$ \\
\hline Log input tariffs $*$ & & & 0.16 & 0.21 & 0.18 \\
\hline Share input imports & & & $(0.07)^{\star \star}$ & $(0.08)^{\star \star \star}$ & $(0.09)^{\star \star}$ \\
\hline \multirow[t]{2}{*}{ Log output tariffs } & & & -0.02 & -0.01 & -0.04 \\
\hline & & & $(0.03)$ & $(0.03)$ & $(0.04)$ \\
\hline Log output tariffs $*$ & & & -0.25 & -0.20 & -0.03 \\
\hline Share exports & & & $(0.15)^{\star}$ & $(0.13)$ & $(0.14)$ \\
\hline Log M\&E tariffs $*$ & & & -0.05 & -0.06 & -0.04 \\
\hline Share M\&E imports & & & $(0.02)^{\star}$ & $(0.03)^{\star \star}$ & $(0.03)$ \\
\hline \multirow[t]{2}{*}{ Log FDI } & & & & 0.67 & 0.77 \\
\hline & & & & $(0.27)^{\star \star}$ & $(0.20)^{\star \star \star}$ \\
\hline Input/export shares & no & no & yes & yes & yes \\
\hline Other plant-level controls & no & no & no & yes & yes \\
\hline Industry-level controls & no & no & no & yes & yes \\
\hline Year fixed effects & yes & yes & yes & yes & yes \\
\hline No. obs. & 9115 & 6085 & 6085 & 6085 & 4555 \\
\hline Wald test & $711.19^{\star \star \star}$ & $741.69^{\star \star \star}$ & $1630.91^{\star \star \star}$ & $2982.69^{\star \star \star}$ & $7140.00^{\star \star \star}$ \\
\hline $\operatorname{AR}(1)$ & $-7.83^{\star \star \star}$ & $-5.79^{\star \star \star}$ & $-4.81^{\star \star \star}$ & $-4.79^{\star \star \star}$ & $-7.76^{\star \star \star}$ \\
\hline $\operatorname{AR}(2)$ & -0.04 & 0.52 & 0.10 & 0.04 & 0.93 \\
\hline
\end{tabular}

Notes: The regressions are estimated via system GMM. The dependent variable is the log of the relative wage of white- to blue-collar workers in all regressions. Robust standard errors in parentheses are clustered at the industry level. One, two and three asterisks indicate coefficients significantly different from zero at $10 \%, 5 \%$ and $1 \%$ level respectively.

in this specification. The relative wage of white- to blue-collar workers is larger in plants with foreign ownership. The inclusion of these additional variables does not, however, affect the statistical significance of the point estimates on the price of M\&E and the trade-related variables, with the exception of the negative coefficient on output tariffs interacted with the share of sales exported that is now not significant.

The preferred interpretation for the negative coefficient on the price of $M \& E$ found so far is that cheaper M\&E may bring about technical change, through mechanization, that favours white-collar workers, but only in larger plants that invest more in M\&E. To confirm this hypothesis, the specification in column (5) includes only those plants in which this mechanization occurred, which is to say plants that invested more in M\&E during this period. The results tend to confirm this hypothesis since the coefficient on the price of $M \& E$ is still negative, significant and of statistically equal magnitude. The coefficients on the other regressors are not affected qualitatively, with the exception of the interaction term between the tariff rate on $\mathrm{M} \& \mathrm{E}$ and the share of $\mathrm{M} \& \mathrm{E}$ imported that is now not significant. 
Table 3: The determinants of the price of M\&E in Mexico

\begin{tabular}{lccc}
\hline \hline Dep. var.: Log M\&E price & & $(2)$ & $(3)$ \\
& $(1)$ & M\&E & Industry \\
& $\begin{array}{c}\text { US price } \\
\text { and year f.e. }\end{array}$ & tariffs & 3.51 \\
& 1.09 & 3.62 & $(0.35)^{\star \star \star}$ \\
Log M\&E price in US & $(0.59)^{\star}$ & $(0.24)^{\star \star \star}$ & 0.38 \\
& & 0.54 & $(0.18)^{\star \star}$ \\
Log M\&E tariffs & yes & $(0.11)^{\star \star \star}$ & yes \\
& no & yes & yes \\
Industry fixed effects & yes & no & 230 \\
Industry-level controls & 230 & 230 & 0.92 \\
Year fixed effects & 0.93 & 0.91 & $63.33^{\star \star \star}$ \\
No. obs. & $277.97^{\star \star \star}$ & $154.34^{\star \star \star}$ & no \\
R-squared & F-test & . &
\end{tabular}

Notes: The regressions are estimated via fixed effects. The dependent variable is the log of the price of $\mathrm{M} \& \mathrm{E}$ in Mexico in all regressions. Robust standard errors in parentheses are clustered at the industry level. One, two and three asterisks indicate coefficients significantly different from zero at $10 \%, 5 \%$ and $1 \%$ level respectively.

\section{Disentangling trade-induced and exogenous SBTC}

Table 3 reports the estimation results for equation (3). This equation is equivalent to the first-stage regression in a two-stage least squares estimation and it is necessary to check the informativeness of the price of M\&E in the US as an instrument, since system GMM does not report the results of this regression, and to look at how the price of M\&E in Mexico is affected by the price of M\&E in the US and the tariff rate specific to M\&E.

The first column of table 3 shows the results including only the log of the price of M\&E in the US, industry fixed effects and year fixed effects. The price of M\&E in the US has a positive coefficient, significant at the $10 \%$ level.

Column (2) adds the tariff rate specific to M\&E, but drops the year fixed effects since the former does not change across industries but only over time. The point estimate of the coefficient on the price of M\&E in the US is still positive and now highly significant due to its larger magnitude. The coefficient on the tariff rate on M\&E is also positive and highly significant, thus highlighting the role of trade liberalization in inducing lower prices of M\&E and consequently, as argued in the previous section, technical change in favour of white-collar workers.

Column (3) includes additional industry-level regressors, as in the set of regressions shown in table 2. The coefficients on the price of M\&E in the US and the tariff rate on $\mathrm{M} \& \mathrm{E}$ are not significantly different from those in column (2).

\section{Results for real skilled and unskilled wages}

Table 4 reports the estimations for equations (4) and (5) and shows four regressions, in which the dependent variable is either real wages of white-collar workers (first two columns) or real wages of blue-collar workers (last two columns). In all the regressions, the estimator used is system GMM. The first and third columns correspond to the specification in column (4) of table 2, while the second and fourth columns report the same 
Table 4: The effects of trade and SBTC on skilled and unskilled wages

\begin{tabular}{|c|c|c|c|c|}
\hline \multirow[t]{2}{*}{ Dep. var. } & \multicolumn{2}{|c|}{ Skilled wage } & \multicolumn{2}{|c|}{ Unskilled wage } \\
\hline & $(1)$ & $(2)$ & $(3)$ & $(4)$ \\
\hline & Plants w/ & $>$ median & Plants w/ & $>$ median \\
\hline & $>100$ empl. & M\&E inv. & $>100$ empl. & M\&E inv. \\
\hline \multirow[t]{2}{*}{ Skilled wage (-1) } & 0.56 & 0.47 & & \\
\hline & $(0.04)^{\star \star \star}$ & $(0.07)^{\star \star \star}$ & & \\
\hline \multirow[t]{2}{*}{ Unskilled wage $(-1)$} & & & 0.44 & 0.56 \\
\hline & & & $(0.04)^{\star \star \star}$ & $(0.04)^{\star \star \star}$ \\
\hline \multirow[t]{2}{*}{ Log M\&E price } & -36.32 & -38.17 & -4.70 & -3.90 \\
\hline & $(9.84)^{\star \star \star}$ & $(13.72)^{\star \star \star}$ & $(8.68)$ & $(2.68)$ \\
\hline \multirow[t]{2}{*}{ Log input tariffs } & -3.13 & -5.43 & -1.70 & -1.38 \\
\hline & $(2.82)$ & $(3.33)$ & $(1.51)$ & (1.11) \\
\hline Log input tariffs $*$ & 1.16 & 3.93 & -3.31 & -2.11 \\
\hline Share input imports & $(5.33)$ & $(4.51)$ & $(2.18)$ & $(1.63)$ \\
\hline \multirow[t]{2}{*}{ Log output tariffs } & 0.29 & 1.32 & 0.16 & -0.25 \\
\hline & $(2.64)$ & $(2.99)$ & $(0.78)$ & $(0.81)$ \\
\hline Log output tariffs $*$ & -14.97 & -11.61 & 0.65 & -0.66 \\
\hline Share exports & $(7.53)^{\star \star}$ & $(6.76)^{\star}$ & $(2.63)$ & $(1.61)$ \\
\hline Log M\&E tariffs $*$ & -2.89 & -2.92 & 0.17 & 0.32 \\
\hline Share M\&E imports & $(1.64)^{\star}$ & $(2.04)$ & $(0.67)$ & $(0.45)$ \\
\hline \multirow[t]{2}{*}{ Log FDI } & 91.83 & 91.46 & 24.11 & 16.79 \\
\hline & $(11.75)^{\star \star \star}$ & $(15.87)^{\star \star \star}$ & $(6.28)^{\star \star \star}$ & $(4.36)^{\star \star \star}$ \\
\hline Input/export shares & yes & yes & yes & yes \\
\hline Other plant-level controls & yes & yes & yes & yes \\
\hline Industry-level controls & yes & yes & yes & yes \\
\hline Year fixed effects & yes & yes & yes & yes \\
\hline No. obs. & 6085 & 4555 & 6085 & 4555 \\
\hline Wald test & $1879.38^{\star \star \star}$ & $1752.75^{\star \star \star}$ & $974.50^{\star \star \star}$ & $973.58^{\star \star \star}$ \\
\hline $\operatorname{AR}(1)$ & $-8.38^{\star \star \star}$ & $-8.23^{\star \star \star}$ & $-6.28^{\star \star \star}$ & $-7.61^{\star \star \star}$ \\
\hline $\operatorname{AR}(2)$ & 0.65 & 0.90 & 0.60 & -0.50 \\
\hline
\end{tabular}

Notes: The regressions are estimated via system GMM. The dependent variable is the real wage of whitecollar workers in columns (1) and (2) and the real wage of blue-collar workers in columns (3) and (4). Robust standard errors in parentheses are clustered at the industry level. One, two and three asterisks indicate coefficients significantly different from zero at $10 \%, 5 \%$ and $1 \%$ level respectively.

specification as in column (5) of table 2, but with the real wage of white-collar workers and the real wage of blue-collar workers as the dependent variables. All specifications are significant overall, as shown by the Wald tests, and only first-order serial correlation is detected by the $\mathrm{AR}(1)$ and $\mathrm{AR}(2)$ tests. To avoid the problem of too many instruments, only one lag of the endogenous variables is included.

Column (1) shows that the price of $M \& E$ has a negative effect on the real wage of white-collar workers, but again only in larger plants, controlling for all the additional regressors. This result carries over when the sample includes only those plants that invest more than the median plant, as in column (2). This suggests that cheaper M\&E may bring about technical change through mechanization that favours white-collar workers, thus leading to higher real wages for skilled workers.

Regarding the other coefficients, the lagged dependent variable, in both estimations for real white- and blue-collar workers' wages, is always positive and significant, with a coefficient less than one. Decreases in tariffs on final goods lead to increases in the real 
wage of white-collar workers in plants that export a larger share of their sales. Also, plants in which foreigners have a stake tend to pay higher wages to white-collar workers.

The results are different for the real wage of blue-collar workers. Column (3) shows the coefficient for the price of $\mathrm{M} \& \mathrm{E}$ is negative but not significant. The sign and significance of the point estimate for the price of $\mathrm{M} \& \mathrm{E}$ does not change when, in column (4), the sample of plants includes only those that invest more than the median plant. This is consistent with the hypothesis that technical change coming from cheaper M\&E favours only white-collar workers.

This specification shows that none of the trade-related variables are significant, while the log of the share of firms' social capital held by foreigners is positive and highly significant. The coefficient is smaller than that on the same variable in the regression for the real wage of white-collar workers, which is consistent with the positive effect of foreign ownership on relative wages.

\section{Robustness checks}

This section presents some robustness checks for the results presented above, starting with the regressions for the skill premium. Table 5 shows that the results presented in table 2, particularly the specification in column (4), considered to be the baseline, are robust across specifications. Similar results, available upon request, are obtained when the sample of plants includes those that invest in $\mathrm{M} \& \mathrm{E}$ more than the median plant.

One of the concerns regarding the measure of technical change used, the price of $\mathrm{M} \& \mathrm{E}$, is that it might not be robust to the inclusion of plant-level measures of technical change. Column (1) includes the amount of money spent on royalties for the use of new technologies to measure technical change, as in Bustos $(2007 ; 2011)$, instead of the price of M\&E. ${ }^{7}$ The coefficient on technology expenditures through royalties is positive but not significant. Column (2) uses imports of M\&E, as in Riaño (2009), as a measure of technical change. ${ }^{8}$ The coefficient on M\&E imports is not statistically different from zero. All three measures of technical change, i.e., the price of $\mathrm{M} \& \mathrm{E}$, technology expenditures and $M \& E$ imports, are included in the specification in column (3). As before, decreases in the price of $\mathrm{M} \& \mathrm{E}$ lead to increases in the relative wage of white- to blue-collar workers, but only in larger plants, while the other measures of SBTC are not significant.

Works by Hanson (1997) and Chiquiar (2008) suggest that the regional dimension is important in determining wage and the return to skill in Mexico. Therefore, column (4) controls for state-year fixed effects to isolate the impact of STBC from the differential impact of market access. This specification does not alter the sign and significance of the point estimates on the price of $M \& E$ and all trade-related variables. Similar results are found when 2-digit sector-year fixed effects are included (results available upon request).

State-sector-year fixed effects are added in column (5) to control for changes in labour supply and for the role of maquiladoras in the demand for labour. The point estimate on the price of $\mathrm{M} \& \mathrm{E}$ is still negative and significant and of even larger magnitude. Among the trade-related variables, only the positive coefficient on the interaction term between

\footnotetext{
${ }^{7}$ It should be noted that only one quarter of the plants acquire technology by expenditures on royalties and, even among these plants, such expenditures are very small relative to sales.

${ }^{8}$ Data on imports of M\&E excludes purchases of imports via other domestic firms (e.g., specialized importers), which may underestimate their importance.
} 
Table 5: The effects of trade and SBTC on the skill premium - robustness checks

\begin{tabular}{|c|c|c|c|c|c|}
\hline \multicolumn{6}{|l|}{ Dep. var.: Skill premium } \\
\hline & (1) & $(2)$ & (3) & (4) & $(5)$ \\
\hline & $\begin{array}{c}\text { Royalties } \\
\text { expenditures }\end{array}$ & $\begin{array}{l}\text { M\&E } \\
\text { imports }\end{array}$ & $\begin{array}{c}\text { All SBTC } \\
\text { measures }\end{array}$ & $\begin{array}{l}\text { State-year } \\
\text { fixed effects }\end{array}$ & $\begin{array}{l}\text { State-sec.-year } \\
\text { fixed effects }\end{array}$ \\
\hline Skill premium $(-1)$ & 0.69 & 0.69 & 0.69 & 0.68 & 0.65 \\
\hline & $(0.08)^{\star \star \star}$ & $(0.08)^{\star \star \star}$ & $(0.08)^{\star \star \star}$ & $(0.09)^{\star \star \star}$ & $(0.08)^{\star \star \star}$ \\
\hline Log M\&E price & & & $\begin{array}{c}-0.50 \\
(0.22)^{\star \star}\end{array}$ & $\begin{array}{c}-0.55 \\
(0.20)^{\star \star \star}\end{array}$ & $\begin{array}{c}-0.73 \\
(0.21)^{\star \star \star}\end{array}$ \\
\hline $\begin{array}{l}\text { Log royalties } \\
\text { expenditures }\end{array}$ & $\begin{array}{c}0.06 \\
(0.12)\end{array}$ & & $\begin{array}{c}0.01 \\
(0.13)\end{array}$ & & \\
\hline Log M\&E imports & & $\begin{array}{c}0.18 \\
(0.12)\end{array}$ & $\begin{array}{c}0.14 \\
(0.12)\end{array}$ & & \\
\hline Log input tariffs & $\begin{array}{l}-0.02 \\
(0.06)\end{array}$ & $\begin{array}{l}-0.03 \\
(0.07)\end{array}$ & $\begin{array}{l}-0.02 \\
(0.06)\end{array}$ & $\begin{array}{l}-0.02 \\
(0.07)\end{array}$ & $\begin{array}{l}-0.02 \\
(0.08)\end{array}$ \\
\hline Log input tariffs * & 0.17 & 0.18 & 0.21 & 0.20 & 0.15 \\
\hline Share input imports & $(0.08)^{\star \star}$ & $(0.08)^{\star \star}$ & $(0.08)^{\star \star \star}$ & $(0.08)^{\star \star}$ & $(0.09)^{\star}$ \\
\hline Log output tariffs & $\begin{array}{l}-0.01 \\
(0.03)\end{array}$ & $\begin{array}{c}0.00 \\
(0.03)\end{array}$ & $\begin{array}{l}-0.02 \\
(0.03)\end{array}$ & $\begin{array}{l}-0.02 \\
(0.03)\end{array}$ & $\begin{array}{l}-0.00 \\
(0.03)\end{array}$ \\
\hline Log output tariffs * & -0.21 & -0.21 & -0.18 & -0.21 & -0.22 \\
\hline Share exports & $(0.14)$ & $(0.14)$ & $(0.13)$ & $(0.13)$ & $(0.14)$ \\
\hline Log M\&E tariffs * & -0.05 & -0.06 & -0.06 & -0.05 & -0.05 \\
\hline Share M\&E imports & $(0.03)^{\star \star}$ & $(0.03)^{\star \star}$ & $(0.03)^{\star \star}$ & $(0.03)^{\star}$ & $(0.03)^{\star \star}$ \\
\hline Log FDI & $\begin{array}{c}0.41 \\
(0.36)\end{array}$ & $\begin{array}{c}0.58 \\
(0.32)^{\star}\end{array}$ & $\begin{array}{c}0.61 \\
(0.31)^{\star \star}\end{array}$ & $\begin{array}{c}0.77 \\
(0.25)^{\star \star \star}\end{array}$ & $\begin{array}{c}0.72 \\
(0.27)^{\star \star \star}\end{array}$ \\
\hline Input/export shares & yes & yes & yes & yes & yes \\
\hline Other plant-level controls & yes & yes & yes & yes & yes \\
\hline Industry-level controls & yes & yes & yes & yes & yes \\
\hline Year fixed effects & yes & yes & yes & yes & yes \\
\hline State-year fixed effects & no & no & no & yes & yes \\
\hline State-sector-year fixed effects & no & no & no & no & yes \\
\hline No. obs. & 6085 & 6085 & 6085 & 6085 & 6085 \\
\hline Wald test & $2968.80^{\star \star \star}$ & $2608.61^{\star \star \star}$ & $3351.50^{\star \star \star}$ & $2.17 \mathrm{e}+09^{\star \star \star}$ & $26431.02^{\star \star \star}$ \\
\hline $\mathrm{AR}(1)$ & $-4.87^{\star \star \star}$ & $-4.84^{\star \star \star}$ & $-4.82^{\star \star \star}$ & $-4.94^{\star \star \star}$ & $-5.28^{\star \star \star}$ \\
\hline $\operatorname{AR}(2)$ & 0.10 & 0.08 & 0.05 & 0.04 & -0.25 \\
\hline
\end{tabular}

Notes: The regressions are estimated via system GMM. The dependent variable is the log of the skill premium in all regressions. Robust standard errors in parentheses are clustered at the industry level. One, two and three asterisks indicate coefficients significantly different from zero at 10\%, $5 \%$ and $1 \%$ level respectively.

input tariffs and the share of imported intermediate inputs and the negative coefficient on the interaction term between the tariff rate on $\mathrm{M} \& \mathrm{E}$ and the share of imported $\mathrm{M} \& \mathrm{E}$ are significant throughout all these additional regressions.

Similar regressions have been run for the specifications using the real wage of whitecollar workers or the real wage of blue-collar workers as the dependent variable. These additional regressions, available upon request, show that the sign and significance of the point estimates in table 4 are robust to the inclusion of plant-level measures of SBTC, i.e., expenditures on royalties and M\&E imports, and state-sector-year fixed effects. In particular, the point estimate for the price of $\mathrm{M} \& \mathrm{E}$ remains negative and significant when the real wage of white-collar workers is the dependent variable but insignificant when the real wage of blue-collar workers is the dependent variable. On the other hand, 
Table 6: Placebo regressions

\begin{tabular}{lccc}
\hline \hline Dep. var.: Skill premium & & & \\
\hline & $(1)$ & $(2)$ & $(3)$ \\
& Machinery and & Construction and & Transportation \\
& equipment & installation & -0.72 \\
\hline Log M\&E price & -0.52 & $(0.62)$ & $(0.09)$ \\
\hline \hline
\end{tabular}

Notes: The regressions are estimated via system GMM. The dependent variable is the log of the relative wage of white- to blue-collar workers in all regressions. Robust standard errors in parentheses are clustered at the industry level. One, two and three asterisks indicate coefficients significantly different from zero at $10 \%, 5 \%$ and $1 \%$ level respectively.

the coefficient on expenditures on royalties is positive and highly significant for both skilled and unskilled wages. This suggests that technical change coming through licenses on technology tends not to favour white-collar workers over blue-collar workers, unlike technical change embodied in $\mathrm{M} \& \mathrm{E}$.

The last set of robustness check done involves two regressions to be considered as placebos. These regressions substitute the price of M\&E from the list of regressors with the prices of two other types of investment, construction and installation and transportation equipment. To compare the new results with the previous ones, column (1) of table 6 replicates the coefficient and standard error associated with the price of M\&E in the specification in column (4) of table 2. Columns (2) and (3) show that the price of the other types of investment does not have an effect on the relative wage of white- to bluecollar workers, thus highlighting the role of $\mathrm{M} \& \mathrm{E}$ in the sharp increase in relative wages in Mexican manufacturing between 1986 and 1990.

\section{Conclusion}

This paper analyses the effects of changes in the price of M\&E and trade liberalization on wages using data at the plant level in Mexican manufacturing from 1984 to 1990. The novelty of this work lies in the use of the price of M\&E as a proxy for SBTC and the identification strategy needed to infer causality.

The results show that decreases in the price of M\&E affect positively and significantly the relative wage of white- to blue-collar workers, a measure for the skill premium. On the other hand, input tariff liberalization tends to decrease relative wages, but only in plants that import a larger share of intermediate inputs. In turn, changes in the price of M\&E in Mexico are found to be associated with changes in the price of M\&E in the US and in tariff rates on $\mathrm{M} \& \mathrm{E}$ in a consistent way.

The evidence presented is consistent with the hypothesis that decreases in the price of M\&E, due to the availability of new and cheaper machines also favoured by trade liberalization, lead to an increased use of $M \& E$ and, thus, technical change that favours skilled workers, but only in plants that invest more in M\&E. Due to complementarity, technical change in those plants that invest more in M\&E leads to an increase in the relative demand for white-collar workers and, thus, higher relative and real skilled wages. The results confirm the importance of firm heterogeneity and technology embodied in machinery, especially in a developing country context, to explain changes in wages. 


\section{References}

Acemoglu, D. (2002a) Directed technical change, Review of Economic Studies, 69, 781809.

Acemoglu, D. (2002b) Technical change, inequality, and the labor market, Journal of Economic Literature, 40, 7-72.

Acemoglu, D. (2003) Patterns of skill premia, Review of Economic Studies, 70, 199-230.

Amiti, M. and Cameron, L. (2011) Trade liberalization and the wage skill premium: Evidence from indonesia, CEPR Discussion Papers 8382, C.E.P.R. Discussion Papers.

Amiti, M. and Davis, D. R. (2012) Trade, firms, and wages: Theory and evidence, Review of Economic Studies, 79, 1-36.

Anderson, E. (2005) Openness and inequality in developing countries: A review of theory and recent evidence, World Development, 33, 1045-1063.

Autor, D. H., Katz, L. F. and Kearney, M. S. (2006) The polarization of the u.s. labor market, American Economic Review, 96, 189-194.

Berman, E., Bound, J. and Griliches, Z. (1994) Changes in the demand for skilled labor within u.s. manufacturing: Evidence from the annual survey of manufactures, The Quarterly Journal of Economics, 109, 367-397.

Bernard, A., Redding, S. and Schott, P. (2009) Multi-product firms and trade liberalization, Working Papers 09-21, Center for Economic Studies, U.S. Census Bureau.

Bloom, N., Draca, M. and Reenen, J. V. (2011) Trade induced technical change? the impact of chinese imports on innovation, it and productivity, CEP Discussion Papers dp1000, Centre for Economic Performance, LSE.

Blundell, R. and Bond, S. (1998) Initial conditions and moment restrictions in dynamic panel data models, Journal of Econometrics, 87, 115-143.

Bobba, M. and Coviello, D. (2007) Weak instruments and weak identification, in estimating the effects of education, on democracy, Economics Letters, 96, 301-306.

Burstein, A. and Vogel, J. (2009) Globalization, technology, and the skill premium, columbia University.

Bustos, P. (2007) The impact of trade on technology and skill upgrading: Evidence from argentina, cREI, Universitat Pompeu Fabra.

Bustos, P. (2011) Trade liberalization, exports, and technology upgrading: Evidence on the impact of mercosur on argentinian firms, American Economic Review, 101, 304-40.

Chennells, L. and Van Reenen, J. (1999) Has technology hurt less skilled workers? a survey of the micro-econometric evidence, IFS Working Papers W99/27, Institute for Fiscal Studies. 
Chiquiar, D. (2008) Globalization, regional wage differentials and the stolper-samuelson theorem: Evidence from mexico, Journal of International Economics, 74, 70-93.

Csillag, M. and Koren, M. (2011) Machines and machinists: Capital-skill complementarity from an international trade perspective, CeFiG Working Papers 13, Center for Firms in the Global Economy.

Davis, D. R. and Harrigan, J. (2011) Good jobs, bad jobs, and trade liberalization, Journal of International Economics, 84, 26-36.

Doms, M., Dunne, T. and Troske, K. R. (1997) Workers, wages, and technology, The Quarterly Journal of Economics, 112, 253-90.

Egger, H. and Kreickemeier, U. (2009) Firm heterogeneity and the labor market effects of trade liberalization, International Economic Review, 50, 187-216.

Esquivel, G. and Rodríguez-López, J. A. (2003) Technology, trade, and wage inequality in mexico before and after nafta, Journal of Development Economics, 72, 543-565.

Fairris, D. and Levine, E. (2004) Declining union density in mexico, 1984-2000, Monthly Labor Review, 127, 10-17.

Feenstra, R. C. and Hanson, G. H. (1996) Globalization, outsourcing, and wage inequality, American Economic Review, 86, 240-45.

Feenstra, R. C. and Hanson, G. H. (1997) Foreign direct investment and relative wages: Evidence from mexico's maquiladoras, Journal of International Economics, 42, 371393.

Felbermayr, G., Prat, J. and Schmerer, H.-J. (2011) Globalization and labor market outcomes: Wage bargaining, search frictions, and firm heterogeneity, Journal of Economic Theory, 146, 39-73.

Feliciano, Z. (2001) Workers and trade liberalization: The impact of trade reforms in mexico on wages and employment, Industrial and Labor Relations Review, 55, 95-115.

Gallego, F. (2010) Skill premium in chile: Studying skill upgrading in the south, Documentos de Trabajo 377, Instituto de Economia, Pontificia Universidad Católica de Chile.

Goldberg, P. K., Khandelwal, A. K., Pavcnik, N. and Topalova, P. (2010) Imported intermediate inputs and domestic product growth: Evidence from india, The Quarterly Journal of Economics, 125, 1727-1767.

Goldberg, P. K. and Pavcnik, N. (2005) Trade, wages, and the political economy of trade protection: evidence from the colombian trade reforms, Journal of International Economics, 66, 75-105.

Goldberg, P. K. and Pavcnik, N. (2007) Distributional effects of globalization in developing countries, Journal of Economic Literature, 45, 39-82. 
Gonzaga, G., Menezes Filho, N. and Terra, C. (2006) Trade liberalization and the evolution of skill earnings differentials in brazil, Journal of International Economics, 68, $345-367$.

Goos, M., Fraumeni, B. M., Manning, A. and Salomons, A. (2009) Job polarization in europe, American Economic Review, 99, 58-63.

Gorodnichenko, Y., Svejnar, J. and Terrell, K. (2010) Globalization and innovation in emerging markets, American Economic Journal: Macroeconomics, 2, 194-226.

Hanson, G. H. (1997) Increasing returns, trade and the regional structure of wages, Economic Journal, 107, 113-33.

Hanson, G. H. and Harrison, A. (1999) Trade liberalization and wage inequality in mexico, Industrial and Labor Relations Review, 52, 271-288.

Harrigan, J. and Reshef, A. (2011) Skill biased heterogeneous firms, trade liberalization, and the skill premium, NBER Working Papers 17604, National Bureau of Economic Research, Inc.

Helpman, E. and Itskhoki, O. (2010) Labor market rigidities, trade and unemployment, Review of Economic Studies, 77, 1100-1137.

Iacovone, L. (2008) Exploring mexican firm-level data, university of Sussex.

Katz, L. F. and Murphy, K. M. (1992) Changes in relative wages, 1963-1987: Supply and demand factors, The Quarterly Journal of Economics, 107, 35-78.

Krusell, P., Ohanian, L. E., Ríos-Rull, J.-V. and Violante, G. L. (2000) Capital-skill complementarity and inequality: A macroeconomic analysis, Econometrica, 68, 10291054.

Kugler, M. and Verhoogen, E. (2012) Prices, plant size, and product quality, Review of Economic Studies, 79, 307-339.

La Porta, R. and López-De-Silanes, F. (1999) The benefits of privatization: Evidence from mexico, The Quarterly Journal of Economics, 114, 1193-1242.

Leamer, E. (1998) In search of stolper-samuelson linkages between international trade and lower wages, in Imports, Exports and the American Worker (Ed.) S. Collins, Brookings Institution, Washington, DC, pp. 141-202.

Levinsohn, J. and Petrin, A. (2003) Estimating production functions using inputs to control for unobservables, Review of Economic Studies, 70, 317-341.

Machin, S. and Van Reenen, J. (1998) Technology and changes in skill structure: Evidence from seven oecd countries, The Quarterly Journal of Economics, 113, 1215-1244.

Melitz, M. J. (2003) The impact of trade on intra-industry reallocations and aggregate industry productivity, Econometrica, 71, 1695-1725. 
Meschi, E., Taymaz, E. and Vivarelli, M. (2009) Trade, technology and skills: Evidence from turkish microdata, Jena Economic Research Papers in Economics 2009-097, Friedrich-Schiller-University Jena, Max-Planck-Institute of Economics.

Revenga, A. (1997) Employment and wage effects of trade liberalization: The case of mexican manufacturing, Journal of Labor Economics, 15, S20-43.

Riaño, A. (2009) Trade, technology adoption and the rise of the skill premium in mexico, university of Nottingham.

Robbins, D. (2003) The impact of trade liberalization upon inequality in developing countries - a review of theory and evidence, ILO Working Paper 13, International Labour Organization.

Roodman, D. (2009) How to do xtabond2: An introduction to difference and system gmm in stata, Stata Journal, 9, 86-136.

Schmidt, G. (2010) Technology choice and international trade, Working Papers 1600, Kiel Institute for the World Economy.

Ten Kate, A. (1989) Notas sobre la apertura comercial de méxico, experiencias y lecciones, Ensayos Sobre Política Económica, 15, 95-111.

Ten Kate, A. (1992) Trade liberalization and economic stabilization in mexico: Lessons of experience, World Development, 20, 659-672.

Topalova, P. (2004) Trade liberalization and firm productivity: The case of india, Working Papers 04/28, IMF.

Van Reenen, J. (2011) Wage inequality, technology and trade: 21st century evidence, Labour Economics, 18, 730-741.

Vannoorenberghe, G. (2011) Trade between symmetric countries, heterogeneous firms, and the skill premium, Canadian Journal of Economics, 44, 148-170.

Verhoogen, E. A. (2008) Trade, quality upgrading, and wage inequality in the mexican manufacturing sector, The Quarterly Journal of Economics, 123, 489-530.

Wood, A. (1994) North-South Trade, Employment and Inequality: Changing Fortunes in a Skill-Driven World, Clarendon Press, Oxford.

Wood, A. (1997) Openness and wage inequality in developing countries: The latin american challenge to east asian conventional wisdom, World Bank Economic Review, 11, 33-57. 